DEGUM-Mitteilungen

Deutsche Gesellschaft für Ultraschall in der Medizin

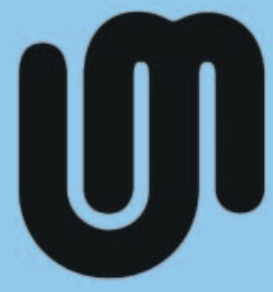

\title{
DEGUM-Ehrenmitglied 2019
}

Während des 43. Dreiländertreffens in Leipzig wurde Prof. Dr. med. Dr. med. dent. Robert Sader, Direktor der Klinik für Mund-, Kiefer- und Plastische Gesichtschirurgie des Universitätsklinikums Frankfurt, mit der DEGUM-Ehrenmitgliedschaft ausgezeichnet.

Unsere herzlichsten Glückwünsche an das diesjährige DEGUM-Ehrenmitglied.

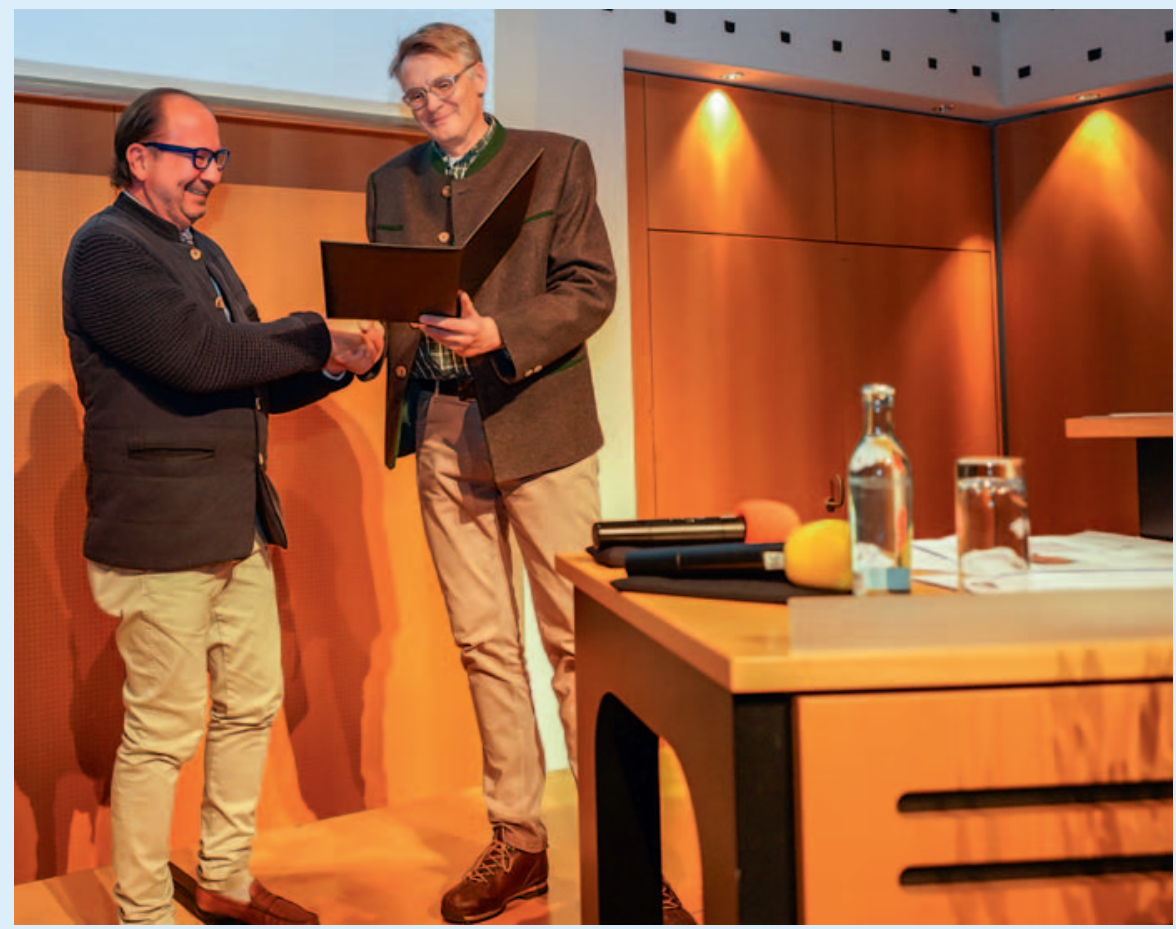

Ehrenmitglied 2019, Prof. R. Sader (links) mit dem Präsidenten der DEGUM, Prof. P. Jecker (rechts). Foto: DEGUM. 